\title{
COST OF FOREST INSURANCE IN THE ECONOMIC VIABILITY OF EUCALYPTUS PLANTS ${ }^{1}$
}

Rafaella Silva Pereira ${ }^{2 *}$, Sidney Araujo Cordeiro ${ }^{3}$, Marcio Leles Romarco de Oliveira $^{3}$, Cristiano Christofaro Matosinhos $^{3}$ and José Benedito Guimarães Junior ${ }^{4}$

\footnotetext{
${ }^{1}$ Received on 10.04.2017 accepted for publication on 23.02.2018.

${ }^{2}$ Universidade Federal dos Vales do Jequitinhonha e Mucuri, Graduada em Engenharia Florestal, Diamantina, MG-Brasil. E-mail: <rafaellaengflorestal@gmail.com>.

${ }^{3}$ Universidade Federal dos Vales do Jequitinhonha e Mucuri, Departamento de Engenharia Florestal, Diamantina, MG-Brasil. E-mail: <sidney.cordeiro@ufvjm.edu.br>,<marcioromarco@gmail.com>and<christofaro@gmail.com>.

${ }^{4}$ Universidade Federal de Lavras, Departamento de Engenharia, Lavras, MG-Brasil. E-mail: <jbguimaraesjr@hotmail.com>.

*Corresponding author.
}

\begin{abstract}
The objective of this study is to carry out economic and risk assessment of eucalyptus plantations located in Minas Gerais, considering the influence of the cost of forest insurance, evidencing its impact on the project. The costs of implementation and driving come from eucalyptus plantations located in the Jequitinhonha Valley, Minas Gerais. The cost of forest insurance was obtained through a simulation of a quote from an insurer. For the economic evaluation, the Net Present Value (NPV), the Internal Rate of Return (IRR) and the Equivalent Periodic Benefit (EPB) were used. The risk sensitivity analysis was performed by the Monte Carlo method. The economic analysis was considered viable by all indicators used in all three situations. However, by the analysis of investment risk, we have a probability of $11.5 \%$ chance of NPV being below zero in situation $1,18.5 \%$ in situation 2 and $25 \%$ in situation 3 . The cost of Forest insurance increases the likelihood of negative value for economic indicators, as it increases the cost of the project, but it was input that less influenced the final value of the NPV. The government grant reduces the likelihood of investment risk as it lowers the cost of forest insurance.
\end{abstract}

Keywords: Forest market; Forest investment; Rural insurance.

\section{CUSTO DO SEGURO DE FLORESTAS NA VIABILIDADE ECONÔMICA DE PLANTIOS DE EUCALIPTO}

\begin{abstract}
RESUMO - Este estudo tem como objetivo realizar análises econômica e de risco de investimento em plantios de eucalipto situados em Minas Gerais, considerando a influência do custo do seguro de florestas, evidenciando o seu impacto no projeto. Os custos de implantação e condução são oriundos de plantios de eucalipto localizados no Vale do Jequitinhonha, Minas Gerais. O custo do seguro de florestas foi obtido por meio de uma simulação de cotação junto à uma seguradora. Para a avaliação econômica utilizou-se o Valor Presente Líquido (VPL), a Taxa Interna de Retorno (TIR) e o Beneficio Periódico Equivalente (BPE). Procedeu-se a análise de sensibilidade de risco pelo método de Monte Carlo. A análise econômica realizada foi considerada viável por todos os indicadores utilizados em todas as três situações trabalhadas. Mas, pela análise de risco de investimento, tem-se a probabilidade de 11,5\% de chances do valor de VPL estar abaixo de zero na situação 1, 18,5\% na situação 2 e $25 \%$ na situação 3 . O custo do seguro de florestas aumenta a probabilidade de valor negativo para os indicadores econômicos, pois ele aumenta o custo do projeto, porém ele foi input o que menos influenciou no valor final do VPL. A subvenção do governo reduz a probabilidade do risco de investimento, uma vez que diminui o custo do seguro de florestas.
\end{abstract}

Palavras-Chave: Mercado florestal, investimento florestal, seguro rural 


\section{INTRODUCTION}

Brazilian territory has about $0.9 \%$ of its area occupied by planted forests (IBÁ, 2015), which in 2014 alone covered 7.74 million hectares. They are located mainly in the states of Minas Gerais (18.83\%), Paraná (17.33\%), Rio Grande do Sul (11.79\%), Santa Catarina (11.04\%), São Paulo(10.70\%) and Mato Grosso do Sul (9.53\%) (IBGE, 2016).

In Minas Gerais, Vale do Jequitinhonha stands out in the forest sector. Although being considered the poorest state region, it presents a growing wood market. Forest activity has gathered a total of 201,174 hectares in the area in 2014, approximately $11.41 \%$ of total forest planting of the Minas Gerais' territory and $2.15 \%$ of Brazil (IBGE, 2016).

Despite the large representation of forest areas throughout the country, natural and planted forests, the forest sector is susceptible to a series of risks, such as the ones associated to adversities (weather and pathogens or pests manifestation), besides the ones common to all productive activities, such as technologic ones, which are related to the evolution and knowledge of technology and the ones caused by economic fluctuations. All of those may significantly compromise forest harvest.

In order tominimize these risks, mainly the ones associated to adversities, some alternatives actions are taken, such as forest insurances. Of the total planted forests area in Brazil, during 2014 alone, only about $3.72 \%$ are covered by forest insurance $(348,568$ hectares $)$ integrated to the Programa de Subvenção do Seguro Rural [Rural Insurance Subsidy Program] (PSR). On Vale do Jequitinhonha, only 23,117.03 hectares are insured by forest insurances linked to PSR, which represents only $1.31 \%$ of the area (Brasil, 2016). This value is very low, which demonstrates that the sector almost ignores the forest insurance and that the economical evaluation study of forest projects involving the costs of this insurance becomes a tool of great value on the promotion of their relevance and viability.

In light of this, the objective of this work is to carry out economic and risk evaluations of eucalyptus plantations located in Minas Gerais, considering the influence of the cost of forest insurance, evidencing its impact on these projects.

\section{MATERIALAND METHODS}

\subsection{Study areas}

Cost data are originated from eucalyptus plantations located on the northeast region of the state of Minas
Gerais, at Vale do Jequitinhonha, more precisely at Alto Jequitinhonha, encompassing the cities: Diamantina, Itamarandiba and Capelinha; and Serro, city located on the metropolitan mesoregion of Belo Horizonte. Spacing was of $3 \times 3$ meters, in a total of approximately $1,111 \mathrm{plants} / \mathrm{ha}$. The average productivity of the forest area is $210 \mathrm{~m}^{3} / \mathrm{ha}$, on the $7^{\text {th }}$ year. The wood's purpose of use is energy.

\subsection{Costs of planting}

The implementation and maintenance cost of eucalyptus planting data (Table 1), the average value of lands and the sale price of wood were obtained from private companies and local producers from Alto do Jequitinhonha and from Serro, to IEF and to EMATER. The price considered was the sale price of stacked up wood at the field edge of $\mathrm{R} \$ 90.00 / \mathrm{m}^{3}$, practiced by individual rural producers and private companies at the region and time of data collection. They were collected in the year 2014 and monetarily restated for July, 2016. The Índice Geral de Preços - Disponibilidade Interna [General Price Index - Internal Availability] (IGP-DI) was used for data restating (IBRE-FGV, 2016a; IBRE-FGV, 2016b).

The average value of lands obtained for the region was of R\$3,589.80 per hectare. Therefore, its annual cost is of $R \$ 314.11$ per hectare, with the rate of $8.75 \%$ per year being used for the calculation, the same rate used by Programa de Plantio Comercial de Florestas [Commercial Forest Planting Program] (Propflora).

\subsection{Forest insurance quotation}

The forest insurance e costs for the study area were obtained through a forest insurance quotation simulation made through a quotation survey of an insurance company. Quotations were simulated for eucalyptus with all kinds of coverage available in the survey, being: basic coverage (fire and lightning) and additional coverages: weather events (excessive rain, hailstorm, frost, drought and waterspout), strong winds and aircraft crash. The simulation was carried out for an area of 1 hectare, with the purpose of use of wood for cellulose/energy. The premium refers to the amount paid yearly, separately calculated for all planting years, considering 2016 as the last year of a 7-year cycle for high trees regimen. The subsidy value of $45 \%$ of the premium amount was considered and the amount paid by the insured party is obtained by the subtraction

Revista Árvore. 2018;42(3):e420302 
of the premium amount from the subsidy, if it occurs. The Insured Party Mandatory Participation (IMP) considered was of $5 \%$ of the planting area risk value.

\subsection{Economical Evaluation}

Three different situations were worked with, being: without the forest insurance costs (first situation), with basic coverage + all additional coverages (weather events + strong winds + aircraft crash), considering the subsidy value (second situation) and with basic coverage + all additional coverages, disregarding the subsidy value (third situation). In this study, the Net Present Value (NPV), the Internal Rate of Return (IRR) and the Equivalent Periodic Benefit (BPE) were used as economical evaluation methods.

\subsubsection{Net Present Value (NPV)}

The economical evaluation carried out through the NPV method (Equation 1) is defined by the algebraic sum of the values discounted from the cash flow associated to the project. The economic viability is determined by the positive difference between revenue and costs, updated according to some predetermined discount rate for the present. Therefore, for positive NPV, there is an economically attractive project and for negative NPV there is an impracticable project (Rezende and Oliveira, 2013).

$$
N P V=\sum_{j=1}^{n} \frac{R_{j}}{(1+i)^{j}}-\sum_{j=1}^{n} \frac{C_{j}}{(1+i)^{j}}
$$

In which: $\mathrm{NPV}=$ Net Present Value; $\mathrm{Rj}=$ revenues in period $\mathrm{j} ; \mathrm{Cj}=$ costs in period $\mathrm{j} ; \mathrm{i}=$ discount rate; $\mathrm{j}=$ occurrence period of $\mathrm{Rj}$ and $\mathrm{Cj}$; and $\mathrm{n}=$ project duration, in years or in number of time periods.

\subsubsection{Internal Rate of Return (IRR)}

The IRR (Equation 2) is the yearly rate of invested capital return, being determined by the equity between the current value of revenues (future) and the current cost value (future) of the undertaking. Therefore, it is the rate that matches the NPV to zero. It is also commonly understood as the average rate of growth in an undertaking, being essential to the Project and independent from the current discount rate adopted. The project is economically viable if the IRR is superior to the compensation discount rate adopted (usually called Minimum Attractiveness Rate (MAR)) (Rezende and Oliveira, 2013).

$$
I R R=\sum_{j=1}^{n} \frac{R_{j}}{(1+T I R)^{j}}-\sum_{j=1}^{n} \frac{C_{j}}{(1+T I R)^{j}}=0 \quad E Q 2
$$

In which: IRR = Internal Rate of Return; $\mathrm{Rj}=$ revenues in period $\mathrm{j} ; \mathrm{Cj}=$ costs in period $\mathrm{j} ; \mathrm{j}=$ occurrence period of $\mathrm{Rj}$ and $\mathrm{Cj}$; and $\mathrm{n}=$ project duration, in years or in number of time periods.

\subsubsection{Equivalent Periodic Benefit (EPB)}

The EPB (Equation 4) is the constant net cash flow, where it is assumed that the first is centered at the end of the initial operation period of the application performed, which presents the same NPV, with equal lifespan to the analyzed investment. In other words, it is the periodic and continuous installment necessary to the payment of an amount equal to the NPV of the evaluated project, during its lifespan. When the periodic benefits are greater than the periodic costs, thus presenting a positive EPB, the project can be said to be economically viable. It takes into account the size of the projects being compared, which is an advantage, since it may dismiss any further analysis (Rezende and Oliveira, 2013).

$$
\mathrm{EPV} \text { or } \mathrm{EPB}(\mathrm{C}) \text { or } \mathrm{EAV}=\frac{\mathrm{VPL} *_{\mathrm{i}}}{1-(1+\mathrm{i})^{-\mathrm{n}}} \quad \mathrm{EQ} 3
$$

In which: EPV or EPB(C) orEAV=Equivalent Periodic Value or Equivalent Periodic Benefit (Cost) or Equivalent Annual Value; EPV = Equivalent Periodic Value; $\mathrm{i}=$ discount rate; and $\mathrm{n}=$ duration of the project, in years.

\subsection{Investment risk analysis}

The sensitivity analysis was performed using the Monte Carlo method. 100,000 interactions were defined and three different situations determined: situation 1, where it was considered as input variables (inputs): annual interest rate, sale price of wood and productivity; situation 2, with the addition of the cost of forest insurance input with basic coverage + all additional (considering the value of the subsidy) and situation 3 with basic coverage + all additional (disregarding the amount of the subsidy). All sensitivity analyzes were designed for the NPV indicator, with it being the output variable (output).

According to Cordeiro et al. (2010) and BentesGama (2005) triangular distribution was used as base. 
Table 1-Costs per hectare for timber production from eucalyptus plantations of the Jequitinhonha Valley (more specifically in the cities: Diamantina, Itamarandiba and Capelinha) and Serro, a municipality of the metropolitan mesoregion of Belo Horizonte, Minas Gerais, Brazil.

Tabela 1 - Custos por hectare para produção de madeira oriunda de plantios de eucalipto do Vale do Jequitinhonha (mais especificamente nas cidades: Diamantina, Itamarandiba e Capelinha) e Serro, município da mesorregião metropolitana de Belo Horizonte, Minas Gerais, Brasil

\begin{tabular}{|c|c|c|c|c|c|c|c|c|c|c|c|c|c|c|}
\hline \multirow[t]{3}{*}{ COST ITEMS } & \multirow[t]{3}{*}{ Unit } & \multirow[t]{3}{*}{ Cost } & \multicolumn{10}{|c|}{ Period } & \multirow{2}{*}{\multicolumn{2}{|c|}{ Total }} \\
\hline & & & \multicolumn{2}{|c|}{$1^{\text {st }}$ year } & \multicolumn{2}{|c|}{$2^{\text {nd }}$ year } & \multicolumn{2}{|c|}{$3^{\text {rd }}$ year } & \multicolumn{2}{|c|}{$4^{\text {th }}$ to $6^{\text {th }}$ year } & \multicolumn{2}{|c|}{$7^{\text {th }}$ year } & & \\
\hline & & & $\mathrm{Amt}$ & $\begin{array}{l}\text { Cost } \\
(\mathrm{R} \$)\end{array}$ & $\overline{\mathrm{Amt}}$ & $\begin{array}{l}\text { Cost } \\
(\mathrm{R} \$)\end{array}$ & $\overline{\mathrm{Amt}}$ & $\begin{array}{l}\text { Cost } \\
(\mathrm{R} \$)\end{array}$ & Amt & $\begin{array}{l}\text { Cost } \\
(\mathrm{R} \$)\end{array}$ & $\overline{A m t}$ & $\begin{array}{l}\text { Cost } \\
(\mathrm{R} \$)\end{array}$ & $\overline{A m t}$ & $\begin{array}{l}\text { Cost } \\
(\mathrm{R} \$)\end{array}$ \\
\hline \multicolumn{15}{|c|}{ 1. INPUTS } \\
\hline $\begin{array}{l}\text { Seedlings } \\
\text { (Planting) }\end{array}$ & Un & 0.4 & $1,111.0$ & 398.8 & & & & & & & & & $1,111.0$ & 398.8 \\
\hline Limestone & $\mathrm{T}$ & 187.3 & 0.1 & 20.6 & & & & & & & & & 0.1 & 20.6 \\
\hline Nitrogen $-\mathrm{N}$ & $\mathrm{Kg}$ & 5.1 & 20.0 & 102.7 & & & & & & & & & 20.0 & 102.7 \\
\hline $\begin{array}{l}\text { Phosphorus - } \\
\text { P2O5 }\end{array}$ & $\mathrm{Kg}$ & 2.8 & 30.0 & 84.4 & & & & & & & & & 30.0 & 84.4 \\
\hline $\begin{array}{l}\text { Potassium - } \\
\mathrm{K} 2 \mathrm{O}\end{array}$ & $\mathrm{Kg}$ & 2.8 & 20.0 & 56.0 & & & & & & & & & 20.0 & 56.0 \\
\hline Anticide & $\mathrm{Kg}$ & 10.9 & 5.0 & 54.7 & 2.0 & 21.9 & 1.0 & 10.9 & 3.0 & 32.8 & 1.0 & 10.9 & 12.0 & 131.4 \\
\hline Termiticide & $\mathrm{Kg}$ & 173.9 & 0.2 & 34.8 & & & & & & & & & 0.2 & 34.8 \\
\hline $\begin{array}{l}\text { SUB-TOTAL } \\
\text { Inputs }\end{array}$ & $\mathrm{R} \$$ & & & 752.0 & & 21.9 & & 10.9 & & 32.8 & & 10.9 & & 828.6 \\
\hline \multicolumn{15}{|c|}{ 2. SERVICES } \\
\hline $\begin{array}{l}\text { Cleaning of } \\
\text { the area }\end{array}$ & $\mathrm{d} / \mathrm{H}$ & 53.8 & 10.0 & 538.5 & & & & & & & & & 10.0 & 538.5 \\
\hline $\begin{array}{l}\text { Marking of } \\
\text { lines }\end{array}$ & $\mathrm{d} / \mathrm{H}$ & 53.8 & 2.0 & 107.7 & & & & & & & & & 2.0 & 107.7 \\
\hline $\begin{array}{l}\text { Marking of } \\
\text { holes }\end{array}$ & $\mathrm{d} / \mathrm{H}$ & 53.8 & 1.0 & 53.8 & & & & & & & & & 1.0 & 53.8 \\
\hline Digging & $\mathrm{d} / \mathrm{H}$ & 53.8 & 11.0 & 592.3 & & & & & & & & & 11.0 & 592.3 \\
\hline $\begin{array}{l}\text { Internal transport } \\
\text { of inputs }\end{array}$ & $\mathrm{d} / \mathrm{H}$ & 53.8 & 1.0 & 53.8 & & & & & & & & & 1.0 & 53.8 \\
\hline $\begin{array}{l}\text { Hole Liming } \\
\text { and Fertilization }\end{array}$ & $\mathrm{d} / \mathrm{H}$ & 53.8 & 3.0 & 161.5 & & & & & & & & & 3.0 & 161.5 \\
\hline Replanting & $\mathrm{d} / \mathrm{H}$ & 53.8 & 8.0 & 430.8 & & & & & & & & & 8.0 & 430.8 \\
\hline Ant control & $\mathrm{d} / \mathrm{H}$ & 95,7 & 2,5 & 239,3 & 1,5 & 143,6 & 1,5 & 143,6 & 4,0 & 382,9 & 1,5 & 143,6 & 11,0 & $1.053,0$ \\
\hline Crowning or in & $\mathrm{d} / \mathrm{H}$ & 53,8 & 9,0 & 484,6 & 2,0 & 107,7 & & & & & & & 11,0 & 592,3 \\
\hline \multicolumn{15}{|l|}{ line manual weeding } \\
\hline Manual grubbing & $\mathrm{d} / \mathrm{H}$ & 53.8 & 6.0 & 323.1 & 6.0 & 323.1 & & & & & & & 12.0 & 646.2 \\
\hline Firebreak & $\mathrm{d} / \mathrm{H}$ & 53.8 & 6.0 & 323.1 & 4.0 & 215.4 & 4.0 & 215.4 & 11.0 & 592.3 & & & 25.0 & $1,346.2$ \\
\hline \multicolumn{15}{|c|}{ Construction/Maintenance } \\
\hline Manual grubbing & $\mathrm{d} / \mathrm{H}$ & 53.8 & 6.0 & 323.1 & 6.0 & 323.1 & & & & & & & 12.0 & 646.2 \\
\hline Firebreak & $\mathrm{d} / \mathrm{H}$ & 53.8 & 6.0 & 323.1 & 4.0 & 215.4 & 4.0 & 215.4 & 11.0 & 592.3 & & & 25.0 & $1,346.2$ \\
\hline \multicolumn{15}{|c|}{ Construction/Maintenance } \\
\hline $\begin{array}{l}\text { Lopping and } \\
\text { Cutting }\end{array}$ & $\mathrm{d} / \mathrm{H}$ & 53.8 & & & & & & & & & 18.0 & 969.2 & 18.0 & 969.2 \\
\hline Transportation & $\mathrm{d} / \mathrm{H}$ & 53.8 & & & & & & & & & 23.0 & $1,238.5$ & 23.0 & $1,238.5$ \\
\hline $\begin{array}{l}\text { SUB-TOTAL } \\
\text { Services }\end{array}$ & $\mathrm{R} \$$ & & & $3,308.6$ & & 789.8 & & 359.0 & & 975.2 & & $2,351.3$ & & $7,783.9$ \\
\hline TOTAL & $\mathrm{R} \$$ & & & $4,060.6$ & & 811.7 & & 369.9 & & $1,008.1$ & & $2,362.3$ & & $8,612.5$ \\
\hline
\end{tabular}

Observation: un: unit; amt: amount

Observação:ud: unidade; quant: quantidade.

Three scenarios were worked with, adopting variations of $\pm 30 \%$ in the inputs, being: most likely, with contextualization of the real scenario of input values, optimistic and pessimistic. Minimum, maximum and average values, standard deviations, mode and percentiles were generated. Based on the elasticities

Revista Árvore. 2018;42(3):e420302 
Table 2 - Forest insurance costs for one hectare of eucalyptus plantation in the study area, calculated annually according to planting age.

Tabela 2 - Custos do seguro de florestas para um hectare de plantio de eucalipto na área de estudo, calculados anualmente de acordo com a idade do plantio

\begin{tabular}{|c|c|c|c|c|c|c|c|c|c|}
\hline $\begin{array}{l}\text { Planting } \\
\text { Year }\end{array}$ & Age & $\begin{array}{c}\text { Logging } \\
\text { Year }\end{array}$ & $\begin{array}{c}\text { RiskValue/ } \\
\text { ha } \\
(\mathrm{R} \$)\end{array}$ & $\begin{array}{l}\mathrm{MCL} \\
(\mathrm{R} \$)\end{array}$ & $\begin{array}{l}\text { Minimum } \\
\text { IMP } \\
(\mathrm{R} \$)\end{array}$ & Coverage & $\begin{array}{c}\text { Net } \\
\text { Premium } \\
(\mathrm{R} \$)\end{array}$ & $\begin{array}{c}\text { Subsidy } \\
\text { Amount } \\
(\mathrm{R} \$)\end{array}$ & $\begin{array}{c}\text { Amount } \\
\text { paid by the } \\
\text { producer(R\$) }\end{array}$ \\
\hline \multirow[t]{4}{*}{2015} & 1 & 2022 & 52.90 & $4,655.60$ & 232.78 & Basic (Fire + Lightning) & 52.25 & 23.51 & 28.74 \\
\hline & & & & & & Weather Insurance & 35.18 & 15.83 & 19.35 \\
\hline & & & & & & Strong Winds & 15.52 & 6.98 & 8.54 \\
\hline & & & & & & Aircraft Crash & 5.17 & 2.33 & 2.85 \\
\hline \multirow[t]{4}{*}{2014} & 2 & 2021 & 68.01 & $5,985.05$ & 299.25 & Basic (Fire + Lightning) & 67.17 & 30.22 & 36.94 \\
\hline & & & & & & Weather Insurance & 45.22 & 20.35 & 24.87 \\
\hline & & & & & & Strong Winds & 19.95 & 8.98 & 10.97 \\
\hline & & & & & & Aircraft Crash & 6.65 & 2.99 & 3.66 \\
\hline \multirow[t]{4}{*}{2013} & 3 & 2020 & 79.34 & $6,982.15$ & 349.11 & Basic (Fire + Lightning) & 78.36 & 35.26 & 43.10 \\
\hline & & & & & & Weather Insurance & 52.75 & 23.74 & 29.01 \\
\hline & & & & & & Strong Winds & 23.27 & 10.47 & 12.80 \\
\hline & & & & & & Aircraft Crash & 7.76 & 3.49 & 4.27 \\
\hline \multirow[t]{4}{*}{2012} & 4 & 2019 & 91.81 & $8,078.97$ & 403.95 & Basic (Fire + Lightning) & 90.66 & 40.80 & 49.87 \\
\hline & & & & & & Weather Insurance & 61.04 & 27.47 & 33.57 \\
\hline & & & & & & Strong Winds & 26.93 & 12.12 & 14.81 \\
\hline & & & & & & Aircraft Crash & 8.98 & 4.04 & 4.94 \\
\hline \multirow[t]{4}{*}{2011} & 5 & 2018 & 102.82 & $9,047.86$ & 452.39 & Basic (Fire + Lightning) & 101.54 & 45.69 & 55.85 \\
\hline & & & & & & Weather Insurance & 68.36 & 30.76 & 37.60 \\
\hline & & & & & & Strong Winds & 30.16 & 13.57 & 16.59 \\
\hline & & & & & & Aircraft Crash & 10.05 & 4.52 & 5.53 \\
\hline \multirow[t]{4}{*}{2010} & 6 & 2017 & 114.93 & $10,113.64$ & 505.68 & Basic (Fire + Lightning) & 113.50 & 51.07 & 62.42 \\
\hline & & & & & & Weather Insurance & 76.41 & 34.39 & 42.03 \\
\hline & & & & & & Strong Winds & 33.71 & 15.17 & 18.54 \\
\hline & & & & & & Aircraft Crash & 11.24 & 5.06 & 6.18 \\
\hline \multirow[t]{4}{*}{2009} & 7 & 2016 & 128.25 & $11,286.00$ & $\mathrm{R} \$ 564.30$ & Basic (Fire + Lightning) & 126.65 & 56.99 & 69.66 \\
\hline & & & & & & Weather Insurance & 85.27 & 38.37 & 46.90 \\
\hline & & & & & & Strong Winds & 37.62 & 16.93 & 20.69 \\
\hline & & & & & & Aircraft Crash & 12.54 & 5.64 & 6.90 \\
\hline
\end{tabular}

Obs: MCL: Maximum Compensation Limit by Contracted Coverage; IMP: Insured Party Mandatory Participation.

Obs:LMI: O Limite Máximo de Indenização por Cobertura Contratada; POS: Participação Obrigatória do Segurado.

generated by the multiple linear regression coefficient, the order of importance of how the input variables previously mentioned influenced the NPV financial criteria was identified (and classified), demonstrating the influence of each one of them on the project profit. That is, by measuring the sensitivity of profit variation according to changes in the interest rate, the sale price of wood, productivity and also the different forms of forest insurance coverage.

\section{RESULTS}

\subsection{Forest insurance quotation}

The quotation of the costs obtained for the studied area forest insurance is presented in Table 2, represented for the unit of one hectare of planting. The highest observed values of insurance are for basic coverage, followed by weather events, strong winds and aircraft crash, in descending order of values. The factors that most influenced the premium amount were: the planting cycle in years, the age and the type of coverage desired in the signing of the insurance policy. The highest values of risk area, IMP and forest insurance premium are for the species most advanced ages.

\subsection{Economic viability}

On Table 3, there is the first situation cash flow (without forest insurance costs), second situation (basic coverage + all additional simulated coverages (weather events + strong winds + aircraft crash)), considering the subsidy value and third (basic coverage + all additional), disregarding the subsidy value. 
Table 3 - Cash flow to the first situation where the production of timber in a hectare of the planted forest under study, without the costs of the forest insurance; Second scenario, with the addition of forest insurance costs with basic coverage + meteorological phenomena + strong winds + aircraft fall, considering the total value of the insurance, considering the government subsidy and third situation, with the addition of insurance costs Of forests with basic coverage + meteorological phenomena + strong winds + aircraft drop, disregarding government subsidy.

Tabela 3 - Fluxo de caixa para a primeira situação, com a produção da madeira em um hectare do plantio florestal sob análise, sem os custos do seguro de florestas; segunda situação, com a adição dos custos do seguro de florestas com a cobertura básica + fenômenos meteorológicos + ventos fortes + queda de aeronave, considerando o valor total do seguro, considerando a subvenção do governo e terceira situação, com a adição dos custos do seguro deflorestas com a cobertura básica + fenômenos meteorológicos + ventos fortes + queda de aeronave, desconsiderando a subvenção do governo

\begin{tabular}{|c|c|c|c|c|c|c|c|c|c|}
\hline \multirow{2}{*}{ Year } & \multicolumn{3}{|c|}{ Situation 1} & \multicolumn{3}{|c|}{ Situation 2} & \multicolumn{3}{|c|}{ Situation 3} \\
\hline & $\begin{array}{c}\text { Costs } \\
(\mathrm{R} \$ / \mathrm{ha})\end{array}$ & $\begin{array}{l}\text { Revenue } \\
\text { (R\$/ha) }\end{array}$ & $\begin{array}{l}\text { Balance } \\
\text { (R\$/ha) }\end{array}$ & $\begin{array}{c}\text { Costs } \\
(\mathrm{R} \$ / \mathrm{ha})\end{array}$ & $\begin{array}{l}\text { Revenue } \\
\text { (R\$/ha) }\end{array}$ & $\begin{array}{l}\text { Balance } \\
\text { (R\$/ha) }\end{array}$ & $\begin{array}{c}\text { Costs } \\
(\mathrm{R} \$ / \mathrm{ha})\end{array}$ & $\begin{array}{l}\text { Revenue } \\
\text { (R\$/ha) }\end{array}$ & $\begin{array}{l}\text { Balance } \\
\text { (R\$/ha) }\end{array}$ \\
\hline 1 & $4,374.70$ & - & $-4,374.70$ & $4,434.16$ & - & $-4,434.16$ & $4,482.81$ & - & $-4,482.81$ \\
\hline 2 & $1,125.76$ & - & $-1,125.76$ & $1,202.20$ & - & $-1,202.20$ & $1,264.75$ & - & $-1,264.75$ \\
\hline 3 & 684.04 & - & -684.04 & 773.21 & - & -773 & 846.18 & - & -846.18 \\
\hline 4 & 650.13 & - & -650.13 & 753.32 & - & -753 & 837. & - & -837.74 \\
\hline 5 & 650.13 & - & -650.13 & 765.69 & - & -765.69 & 860.24 & - & -860.24 \\
\hline 6 & 650.13 & - & -650.13 & 779.31 & - & -779.31 & 884.99 & - & -884.99 \\
\hline 7 & $2,676.38$ & $18,900.00$ & $16,223.62$ & $2,820.52$ & $18,900.00$ & $16,079.48$ & $2,938.46$ & $18,900.00$ & $15,961.54$ \\
\hline otal & $10,811.27$ & $18,900.00$ & $8,088.73$ & $11,528.42$ & $18,900.00$ & $7,371.58$ & $12,115.18$ & $18,900.00$ & $6,784.82$ \\
\hline
\end{tabular}

The NPV, IRR and EPB of the studied project, in all three situations are presented in Table 4 . The planting economic viability analysis, by means of all indicators, in all situations presented demonstrated to be economically positive. In the first situation (without the cost of forest insurance), there are the highest values for the economic viability indicators, since it has the lowest total costs.

\subsection{Investment risk analysis}

Table 5 shows, according to the simulation results generated for NPV, that the percentage analysis indicated that $5 \%$ of the values are below - R $\$ 662.63 /$ ha and $5 \%$ of the values are above $\mathrm{R} \$ 5,594.08 /$ ha in situation 1. In situation $2,5 \%$ of the values are below -R $\$ 1,159.95 /$ ha and $5 \%$ of the values are above R $\$ 5,069.17 /$ ha. For situation 3, it is shown that $5 \%$ of the values are above $\mathrm{R} \$ 4,660.89$ and 5\% below -R \$ 1,558.96.

It is possible to verify that there is approximately $11.5 \%$ chance of the NPV value to be below zero

Table 4 - Economic indicators (NPV, IRR and EPV) for situations 1,2 and 3 worked.

Tabela 4 - Indicadores econômicos (VPL, TIR e VPE) para as situações 1, 2 e 3 trabalhadas

\begin{tabular}{cccc}
\hline Indicator & Situation 1 & Situation 2 & Situation 5 \\
\hline NPV & $\mathrm{R} \$ 2,226.95$ & $\mathrm{R} \$ 1,730.33$ & $\mathrm{R} \$ 1,324.01$ \\
$\mathrm{IRR}$ & $15.07 \%$ & $13.61 \%$ & $12.45 \%$ \\
$\mathrm{EPV}$ & $\mathrm{R} \$ 438.77$ & $\mathrm{R} \$ 340.92$ & $\mathrm{R} \$ 260.86$ \\
\hline
\end{tabular}

in situation $1,18.5 \%$ in situation 2 and $25 \%$ in situation 3 .

In situation 1 , if there is a $10 \%$ increase of the interest rate value, there is a $2.5 \%$ decrease in the NPV and for a $10 \%$ increase in the IMA or the sale price of wood, there is an increase of $6.8 \%$ in the NPV value. In situation 2, for a $10 \%$ increase in interest rates and forest insurance, there is a decrease of $2.4 \%$ and $0.3 \%$ of the inputs mentioned, respectively; and for IMA or sale price of wood, there is an increase of $6.8 \%$ in NPV value for a $10 \%$ increase of each. In situation 3 , there is a decrease of $0.6 \%$ and $2.4 \%$ of the NPV, if there is a $10 \%$ increase in interest rates and forest insurance costs, respectively; and for IMA or sale price of wood, there is a $6.8 \%$ increase in NPV value for a $10 \%$ increase of each.

\section{DISCUSSION}

\subsection{Forest insurance quotations}

Forest fires cause serious economic losses, mainly to the productive sector. It is not difficult to see how damaging a forest fire is, even one of low intensity, because in addition to causing temporary decrease in the growth of trees, they present a worse financial result in the whole project (Neumann, 1996). This justifies the higher value of insurance being associated with basic coverage (fire + lightning) and warns of the importance of producer's assets through the contracting

Revista Árvore. 2018;42(3):e420302 
Table 5 - Statistics of the output variables (NPV) and input variables (interest rate, IMA, wood selling price) for situation 1 (without the cost of forest insurance), situation 2 (basic cover + all additional, considering the Value of the grant) and situation 3 (basic cover + all additional, disregarding the value of the grant).

Tabela 5 - Estatísticas das variáveis de saída (VPL) e variáveis de entrada (taxa de juros, IMA, preço de venda da madeira) para a situação 1 (sem o custo do seguro de florestas), situação 2 (cobertura básica + todas adicionais, considerando o valor da subvenção) e situação 3 (cobertura básica + todas adicionais, desconsiderando o valor da subvenção)

\begin{tabular}{|c|c|c|c|c|c|c|c|}
\hline \multirow[t]{3}{*}{ STATISTIC } & \multicolumn{3}{|c|}{ INCOME VARIABLES } & \multirow{3}{*}{$\begin{array}{l}\text { Cost of } \\
\text { Insurance }\end{array}$} & \multicolumn{3}{|c|}{ OUTCOME VARIABLES } \\
\hline & \multirow[t]{2}{*}{ Interest Rate } & \multirow[t]{2}{*}{ IMA } & \multirow[t]{2}{*}{ Sale Price } & & \multicolumn{3}{|c|}{ NPV (R\$) } \\
\hline & & & & & Situation 1 & Situation 2 & Situation 3 \\
\hline Minimum & $6.13 \%$ & 21.03 & $\mathrm{R} \$ 63.07$ & $70.10 \%$ & $-3,077.04$ & $-3,456.81$ & $-3,987.14$ \\
\hline Maximum & $11.33 \%$ & 38.97 & $\mathrm{R} \$ 116.93$ & $129.88 \%$ & $11,038.65$ & $9,837.83$ & $9,475.77$ \\
\hline Average & $8.74 \%$ & 30 & $\mathrm{R} \$ 90.00$ & $100.00 \%$ & $2,253.75$ & $1,756.12$ & $1,348.65$ \\
\hline Standard Deviation & $1.06 \%$ & 3.67 & $\mathrm{R} \$ 11.02$ & $12.25 \%$ & $1,902.35$ & $1,897.78$ & $1,893.41$ \\
\hline \multicolumn{8}{|c|}{ Percentage } \\
\hline $5 \%$ & $6.96 \%$ & 23.85 & $\mathrm{R} \$ 71.54$ & $79.00 \%$ & -662.63 & $-1,159.95$ & $-1,558.96$ \\
\hline $25 \%$ & $7.98 \%$ & 27.36 & $\mathrm{R} \$ 82.09$ & $91.00 \%$ & 876.87 & 385.83 & -22.20 \\
\hline $50 \%$ & $8.74 \%$ & 30 & $\mathrm{R} \$ 90.00$ & $100.00 \%$ & $2,143.92$ & $1,635.60$ & $1,237.55$ \\
\hline $75 \%$ & $9.50 \%$ & 32.64 & $\mathrm{R} \$ 97.91$ & $109.00 \%$ & $3,500.39$ & $3,011.33$ & $2,598.55$ \\
\hline $95 \%$ & $10.52 \%$ & 36.15 & $\mathrm{R} \$ 108.46$ & $121.00 \%$ & $5,594.08$ & $5,069.17$ & $4,660.89$ \\
\hline
\end{tabular}

of forest insurance. It is necessary to have a very solid knowledge about the risks of forest fires in the region intended for planting. The lack of information on forest fires can lead to extremes: high expenditures on prevention for lack of knowledge of the potential for damage or very small investments, putting the survival of the forest at risk (Vosgerau, 2005).

When contracting forest insurance, the producer must have a great knowledge about the main weather risks to which their planting area is exposed, which will make it easier to choose the coverage that best suits them. In some states of South Brazil, there are few sites with no risk of severe frost, that is, with less than one frost every ten years (Wrege et al., 2004). As most of forest plantations do not return investments made before the age of four or five years, in areas where there is knowledge of the occurrence of risks of this type of event, it is a factor that must be considered throughout the whole plantation planning, and the forest insurance is an interesting option for reducing producer's investment risk.

The study region of this work suffers from scarce rainfall regimes, and fires may occur throughout the year caused by drought, which may justify the contracting of basic coverage (fire + lightning) with the additional coverage of weather events, which covers intense droughts. On the other hand, it is known that, in this region, the additional coverage of aircraft crash is not a risk threatening event, therefore it can be waived, avoiding such cost.
It is worth noting that known pests and diseases are considered as risks not covered by forest insurance. This particularity is somewhat unfavorable to this type of insurance and therefore, to deal with such risks, the producer must have specialized technical assistance from the beginning of the planting in order to reduce its incidence. Thus, the producer should investigate which are the most frequent diseases and pests in the planting region, selecting a genetic material that is resistant to the main types present in the region, always considering the intended end use of the wood. Eucalyptus grandis and E. cloeziana, for example, are the most sensitive species to the attack of rust, while E. pellita, E. urophylla and Corymbia citriodora are resistant (Carvalho et al., 1998). One of the strategies that may be adopted to control pests is the Integrated Pest Management (IPM), which selects a series of control techniques depending on each particular situation. It aims at the early detection of outbreaks and their geographic distribution, to evaluate the population density of the pest and the effectiveness of the control measures (Gallo, 2002).

\subsection{Economic viability}

In the three situations presented, it is generally perceived that in forest activities, costs are higher in the first two years since they are related to planting implementation and maintenance process, and also in the last year, which represents the costs of harvesting and transport of wood. 
It is noted that the cost of forest insurance increases the total cost of the planting analysis at seven years, which directly influences the indicators of economic viability. Therefore, the economic indicators are higher for the situation in which there is no contracting of forest insurance (situation 1) than in situations 2 and 3 , where there is the cost of insurance.

By the NPV and IRR methods, there is a positive economic viability of planting in the three situations presented. In situation 1 , the values indicate that the decapitalized income would be higher than the decapitalized costs, even if the market worked with rates exceeding $8.75 \%$ per year, up to the limit of $15.07 \%$ per year; rate where revenues would equal costs. In a situation of wood harvested for purposes similar to those presented in this work, Rezende et al. (2006) obtained an IRR of $22 \%$ for the same minimum rate of attractiveness adopted here $(8.75 \%)$ and the same planning horizon ( 7 years). This difference can be explained mainly due to the increase in the costs of forest planting implementation since the year of development of the aforementioned work. For the EPV of the same situation there is also the viability of eucalyptus planting in the area, reflecting the annual profit of the project. Rode et al. (2015) carried out a work in areas of forest development in the state of Minas Gerais, which despite presenting some differences in regard to this study, mainly on the costs of inputs being subsidized by the companies of the development program, lower interest rate $(5 \%)$ and lower wood sales price $\left(\mathrm{R} \$ 69.37 / \mathrm{m}^{3}\right)$, reached an EPV of R $\$ 421.88$.

\subsection{Investment risk analysis}

It is noticed that the project has reasonable chances of having an NPV value below 0 in both situations presented, which would make the investment unviable. But the subsidy reduces the risk of negative NPV, since it generates a decrease of the costs.

The net profitability of the forest depends on oscillating factors, such as: price, production purpose, area productivity, etc. (Rezende et al., 2006). Thus, analyzing the elasticity based on the economic indicator, we can see that its positive values indicate a direct relation between the input and output variables, with the opposite occurring when they present negative values.

The input variables that most affected the NPV, in increasing order of importance, that is, from the ones that affected the most to the ones that affected the least, were: selling price of wood and IMA (in equal order of importance); interest rate; and lastly the cost of forest insurance, respectively. In risk analyzes performed by Cordeiro et al. (2010) for standing eucalyptus wood production and charcoal production, respectively, prices and production were also obtained as the main factors affecting NPV. However, in the work carried out by Bentes-Gama (2005), which analyzed the risk of investment in agroforestry systems in the city of Machadinho d'Oeste, Rondônia, the variable that most affected the NPV was the interest rate, followed by the price of cupuaçu. It can be seen that from of all the inputs considered, the cost of forest insurance was the one that affected the project NPV the least.

\section{CONCLUSION}

The eucalyptus plantation, for the three established situations, was considered economically viable by all the indicators used in the economic analysis of this study.

By the investment risk analysis it is noted that there is a probability of having negative values for NPV, where there would be an absence of financial return; however the subsidy reduces the likelihood of investment risk. The NPV was influenced in order of importance, respectively, by: selling price of wood and IMA in order of equal importance; interest rate; and the cost of forest insurance. Thus, of all the inputs considered, the cost of forest insurance was the one that had the least influence on the final value of the NPV.

Forest insurance in Brazil requires studies on the adoption of public policies that will help in the marketing of other types of additional coverage by the insurance companies. The implementation of applications focused on the other categories of rural insurance, especially forest insurance; with policies directed to each state in a differentiated manner, according to their forest production, for example, would facilitate the development of the commercialization of such modality.

\section{REFERENCES}

Bentes-Gama MM, Silva ML, Vilcahuamán LJM, Locatelli M. Análise econômica de sistemas agroflorestais na Amazônia Ocidental, Machadinho D'oeste- RO. Revista Árvore. 2005;29(3)401-11.

Revista Árvore. 2018;42(3):e420302 
Cordeiro SA, Silva ML, Jacovine LAG, Valverde SR, Soares NS. Contribuição do fomento do órgão florestal de Minas Gerais na lucratividade e na redução de riscos para produtores rurais. Revista Árvore. 2010;34(2):367-76.

Carvalho AO, Alfenas AC, Maffia LA, Carmo MGF. Resistência de espécies, progênies e procedências de Eucalyptus à ferrugem, causada por Puccinia psidii Winter. Pesquisa Agropecuária Brasileira. 1998;33(2):139-47.

Indústria Brasileira de Árvores - IBÁ. Relatório IBÁ 2015. [accessed on: June 16, 2016]. Available at: http://iba.org/images/shared/iba_2015.pdf

Sistema Instituto Brasileiro de Geografia e Estatística. Recuperação Automática. IBGESIDRA. Produção da extração vegetal e da silvicultura. [accessed on: Aug 02, 2016]. Available at: http://www.sidra.ibge.go;br/bda/ tabela/listabl.asp? $\mathrm{c}=5930 \& \mathrm{z}=\mathrm{p} \& \mathrm{o}=30$.

Gallo D. Entomologia agrícola. Piracicaba: FEALQ; 2002.920p.

Instituto Brasileiro de Economia - Fundação Getúlio Vargas. IBRE - FG. IGP-DI de junho de 2016/IGP-DI mês e 12 meses. 2016a. [accessed on: Aug 23, 2016]. Available at: http://portalibre.fg;br/ main.jsp?lumPageId=402880811DF9ADC4011E 2274DD15152C\&query=igp-di+fev+2016.

Instituto Brasileiro de Economia - Fundação Getúlio Vargas. IBRE - FG. IGP-DI de julho de 2016b. 2016. [accessed on: Aug 23, 2016]. Available at: http://portalibre.fg;br/ main.jsp?lumPageId=402880811DF9ADC4011E2274DD1515
2 C\&query $=$ igp $-\mathrm{di}+\mathrm{fev}+2016$.

Brasil. Ministério da Agricultura, Pecuária e Abastecimento. [accessed on: May 25, 2016] Available at: http://indicadores.agricultura.go;br/ atlasdoseguro/index.htm

Neumann ML. Aspectos técnicos e econômicos da proteção contra incêndios florestais em povoamentos de Pinus sp: [dissertação] Curitiba: Universidade Federal do Paraná; 1996.

Rezende JLP, Oliveira AD. Análise econômica e social de projetos florestais. $3^{\mathrm{a}} \mathrm{ed}$. Viçosa, MG: UFV; 2013. 385p.

Rezende JLP, Padua CTJ, Oliveira AD, Scolforo JRS. Análise econômica de fomento florestal com eucalipto no Estado de Minas Gerais. Cerne. 2006;12(3):221-31.

Rode R, Leite HG, Oliveira MLR, Binoti DHB, Ribeiro CAAS, Souza AL, et al. Comparação da regulação florestal de projetos de fomento com áreas próprias de empresas florestais. Pesquisa Florestal Brasileira. 2015;35(81):11-19.

Vosgerau JL. Análise dos incêndios florestais registrados pelo corpo de bombeiros no estado do Paraná no período de 1991 a 2001

[dissertação]. Curitiba: Universidade Federal do Paraná; 2005.

Wrege MS, Caramori PH, Gonçalves ACA, Bertonha A, Caviglione JH, Faria RT, et al. Ocorrência da primeira geada de outono e última de primavera no Estado do Paraná. Revista Brasileira de Agrometeorologia. 2004;12(1):143-50. 